\title{
ON THE SPECIAL RHEOLOGICAL PROPERTIES OF ANCIENT MICROPARTICLE-LADEN NORTHERN HEMISPHERE ICE AS DERIVED FROM BORE-HOLE AND CORE MEASUREMENTS
}

\author{
By D.A. FisHeR and R.M. KOERNER \\ (Glacier Physics Section, Polar Continental Shelf Project, Energy, Mines and Resources Canada, Ottawa, \\ Ontario K1A 0E4, Canada)
}

AbSTRACT. In the Northern Hemisphere, ice layers which have high microparticle concentrations (in particular late Wisconsin) are "softer" than modern or Holocene ice. Such ice deforms more readily in bore-hole tilt and closure measurements. This enhancement in flow, which is shown not to be related to $c$-axis concentration, has a maximum of three for late Wisconsin ice. The closure and tilt of a bore hole in the Agassiz Ice Cap, Ellesmere Island, drilled in 1977, has been followed every year since its drilling and the flow enhancement observed has been compared to the following quantities measured in the cores: microparticle concentration, $\delta\left({ }^{18} \mathrm{O}\right)$, crystal size, c-axis, Ca, Na, conductivity, and density. Flow enhancement of the ice age and bottom ice was found to be unrelated to $c$-axis concentration and density. Enhancement of flow is best related to microparticle (or $\mathrm{Ca}$ ) concentration which in turn seems to be inversely related to crystal size. The latter relationship also seems to hold for the Devon Island Ice Cap and Greenland. In future, modellers of northern ice ages should use model ice that is three times softer than modern or Holocene ice.

RÉsume. A propos des propriêtés rhéologiques spéciales de la glace ancienne de l'hémisphère nord à couches de microparticules à partir des mesures effectuées dans les forages et les carottages. Dans l'hémisphère nord, des couches de glace à forte concentration en microparticules (notamment celle du Wisconsin récent) sont plus "douces" que celles de la glace contemporaine ou holocène. Une telle glace se déforme plus nettement dans les pendage de forage ou les fermetures de trou. Cette augmentation de fluage, qui n'est pas en relation avec la distribution des axes $c$, présente un maximum ou trois pour la glace du Wisconsin récent. La fermeture et l'inclinaison d'un trou de forage dans la calotte de glace Agassiz, Ellesmere Island, foré en 1977 , ont été suivies chaque année depuis sa réalisation, et l'augmentation de fluage observée a èté comparée aux paramètres suivants mesurés sur les carottes: concentration en microparticules, $\delta\left({ }^{18} \mathrm{O}\right)$, taille des cristaux, axes $c, \mathrm{Ca}, \mathrm{Na}$,

\section{BACKGROUND}

Over the last 15 years ice-coring in the Northern Hemisphere has shown ice laid down during the last (Wisconsin) ice age has special physical and rheological properties. Koerner (1975) noted that Wisconsin ice from Camp Century and Devon Island has a high dirt, Ca, and $\mathrm{Mg}$ content, and consists of fine crystals. Paterson (1977) reported that bore-hole closure was greatly enhanced for the Wisconsin ice of Devon Island, and Hooke (1973) stated that shear tilting of bore holes in the Barnes Ice Cap was a maximum for Wisconsin ice. Also, from two Devon Island Ice Cap cores, Koerner and Fisher (1979) showed late Wisconsin ice contained high concentrations of microparticles in anti-phase with the crystal size. In general, it seems that conductivité et densité. L'augmentation de fluage de cette glace ancienne ainsi que celle du fond n'a pas été trouvée en accord avec la répartition des axes $c$, ni de la densité. L'augmentation de fluage est bien reliée à la concentration en microparticules (ou $\mathrm{Ca}$ ) qui à leur tour apparaissent en opposition avec la taille des cristaux. Cette dernière relation semble aussi être valable pour la calotte de glace de Devon Island et du Groenland. A l'avenir, les modélisateurs des glaces anciennes de l'hémisphère nord devraient adopter des caractéristiques pour la glace qui soient trois fois plus "douces" que celles de la glace contemporaine ou Holocène.

ZuSAMMENFASSUNG. Über die speziellen rheologischen Eigenschaften alten, mit Mikropartikeln beladenen Eises der nördlichen Hemisphäre, hergeleitet aus Bohrloch- und -kernmessungen. Auf der nördlichen Hemisphäre sind Eisschichten, die eine hohe Anreicherung an Mikropartikeln aufweisen (vor allem aus der späten Wisconsin-Kaltzeit), "weicher" als neuzeitliches oder holozänes Eis. Solches Eis deformiert sich leichter bei Messungen der Verbiegung und des Schliessens von Bohrlöchern. Diese Erhöhung der Fliessfähigkeit, die nachweislich nicht mit einer Konzentration der $c$-Achsen verbunden ist, weist ein Maximum von Drei für Eis aus der späten Wisconsin-Kaltzeit auf. Das Schliessen und die Neigung eines Bohrloches im Aggassiz Ice Cap, Ellesmere Island, gebohrt 1977, wurde seit seiner Bohrung jährlich verfolgt und die beobachtete Steigerung des Flusses wurde mit folgenden, an Bohrkernen gemessenen Werten verglichen: Konzentration der Mikropartikel, $\delta\left({ }^{18} \mathrm{O}\right), \quad$ Kristallgrösse, $c$-Achsen, $\mathrm{Ca}$, Na, Leitfähigkeit und Dichte. Flussteigerungen bei Eis aus der Eiszeit und vom Untergrund erwiesen sich als unabhängig von der $c$-Achsen-Konzentration und Dichte; sie sind am stärksten mit der Konzentration an Mikropartikeln (oder $\mathrm{Ca}$ ) korreliert, die wiederum invers von der Kristallgrösse abhängen. Die letztgenannte Beziehung scheint auch für das Devon Island Ice Cap und für Grönland zu gelten. Künftig sollten Modellrechnungen für Eiszeiten im Norden der Erde ein Modelleis voraussetzen, das dreimal weicher als neuzeitliches oder holozänes Eis ist.

the relationship between very high microparticle concentrations, small ice crystals, and enhanced ice flow is stronger in Arctic ice masses than in the Antarctic where the terrestrial impurity content is of a lower order of magnitude (Cragin and others, 1977; Thompson, 1977).

Continuous bore-hole closure and $\delta\left({ }^{18} \mathrm{O}\right)$ profiles through Wisconsin ice of the Agassiz Ice Cap, Ellesmere Island (Fisher, 1981), confirmed the earlier spot value from the Devon Island Ice Cap (Paterson, 1977). More recently, Gundestrup and Hansen (1984), Dahl-Jensen (1985), and Reeh and others (1985) have published analyses of the new Dye 3, Greenland, bore-hole diameter and tilt measurements that confirm enhanced Wisconsin closure and tilt, and further point out that both seem to correlate best with microparticle content. Laboratory tests of Holocene and 
Wisconsin ice from many drill sites in both hemispheres have assessed the relative importance of flow-enhancement factors related to crystal (c-axis) alignment and impurity content (Shoji and Langway, 1984; Azuma, unpublished).

These laboratory studies confirm the field observations that ice-age ice is rheologically different (weaker) than Holocene ice. However, Paterson's (1983) analysis of tilt measurements from the Camp Century, Greenland, and Byrd Station, Antarctica, holes comes to the opposite conclusion; namely, that shear strain-rates for Holocene ice are about three times those of Wisconsin ice. New surveys of these holes, combined with additional surface data, might change his conclusions. Also, extensive studies of a suite of bore holes and cores from Law Dome, Antarctica, show an enhancement maximum above the Wisconsin ice. The enhancement in this case is due to $c$-axis concentration (Russell-Head and Budd, 1979) and not impurities.

The present work condenses 7 years of measurements of bore-hole closure and four inclination surveys in a $338 \mathrm{~m}$ hole drilled in the Agassiz Ice Cap, Ellesmere Island (Fisher and others, 1983). The resulting strain-rates are compared to other measured quantities $\delta\left({ }^{18} \mathrm{O}\right)$, dust, crystal size, density, conductivity, $\mathrm{Na}, \mathrm{Ca}$, and $c$-axis orientation.

Fisher (1981) and Herron and Langway (1982) warned modellers that, because Wisconsin ice is rheologically different from modern ice, their efforts to model ancient ice should not use natural modern flow-law constants.

\section{THE BORE HOLES AND ICE CAP}

An ice cap, roughly $16000 \mathrm{~km}^{2}$ in area, covers the central part of Ellesmere Island between lat. $79^{\circ} 45^{\prime}$ and $81^{\circ} \mathrm{N}$. Its surface topography is complex and there are nunataks even in the highest parts. The ice cap is drained by glaciers that penetrate the surrounding mountains; the larger ones reach sea-level. The northern part - the Agassiz Ice Cap - is where three cores were recovered in 1977, 1979 , and 1984. Hole 77 (338 $\mathrm{m}$ deep) is $1 \mathrm{~km}$ down-slope from a local ice divide at an elevation of $1700 \mathrm{~m}$. Hole 79 ( $139 \mathrm{~m}$ deep and $27 \mathrm{~m}$ higher) is $200 \mathrm{~m}$ down the opposite slope of the divide. Hole 84 is within $10 \mathrm{~m}$ of the highest point of the local ice dome, as determined by precision levelling, and is about $1.2 \mathrm{~km}$ from the 1979 hole and $30 \mathrm{~m}$ higher. Down-bore-hole photography and television confirmed that all holes reached the base of the ice. The $12 \mathrm{~m}$ and basal temperatures are $\left(-24.2^{\circ}\right.$ and $\left.-16.7^{\circ} \mathrm{C}\right)$, $\left(-22.4^{\circ}\right.$ and $\left.-19^{\circ} \mathrm{C}\right)$, and $\left(-22^{\circ}\right.$ and $\left.-19.1^{\circ} \mathrm{C}\right)$ for 77,79 , and 84 holes, respectively. Annual precipitation is $0.175 \mathrm{~m} \mathrm{year}^{-1}$ ice equivalent. But, about $30 \%$ of it (the winter snow) is presently scoured from the 79 and 84 sites (Fisher and others, 1983), and none from the 77 site.

Summer melting, as shown by ice layers in the firn, is slight, on average $3 \%$ of the annual precipitation. Only results from the 77 hole are discussed in detail here. A later paper will deal with a comparison of the three holes.

A CRREL thermal drill produced the 77 hole and it was everywhere within $1 / 2^{\circ}$ of vertical and, for depths below $200 \mathrm{~m}, 0.1650 \pm 0.0005 \mathrm{~m}$ in diameter. Within hours of completion, the hole was partially filled with Arctic diesel oil (density $815 \mathrm{~kg} / \mathrm{m}^{3}$ ) to a depth of $60 \mathrm{~m}$ below the surface. This oil depth remained constant $\pm 2 \mathrm{~m}$ for the 7 years of the study. There is a constant under-pressure (e.g. $0.705 \mathrm{MN} / \mathrm{m}^{2}$ at the bottom) closing the hole $\left(\mathrm{MN} / \mathrm{m}^{2}=\right.$ $10^{6} \mathrm{~N} / \mathrm{m}^{2}=10^{6} \mathrm{~Pa}$ )

The ice-age ice, as defined by very negative $\delta\left({ }^{18} \mathrm{O}\right)$ values, is confined to a layer between $3.5 \mathrm{~m}$ and $8 \mathrm{~m}$ above the bed (see Fig. 1c). It also has high microparticle concentrations (Fig. 1b), small crystal sizes (Fig. 1d), high hole-closure rates (Fig. Ia), high shear rates (Fig. 1i), and high $\mathrm{Ca}$ and $\mathrm{Na}$ concentrations (Fig. le and f). The (optic) $c$-axes (Fig. 1j) are highly concentrated already by $y=9 \mathrm{~m}$ ( $y$ is the distance over the bed) and show little change for older, deeper ice except for one thin section at $y=3 \mathrm{~m}$ which consists of very coarse ice.

Holocene, Wisconsin, and pre-Wisconsin ice are found under nearly identical stress and temperature $\left(-16.9^{\circ} \mathrm{C}\right)$ conditions. Thus, one can immediately eliminate these variables as causes of any of the differences in strainrates.

The close relationship between $\delta\left({ }^{18} \mathrm{O}\right)$, microparticles, and crystal size (Fig. 1c, b, and d) parallels closely that found in two Devon Island Ice Cap cores (Koerner and Fisher, 1979).

\section{DIAMETERS AND CLOSURE RATES}

Diameters were measured continuously by a Pollak and Skan caliper (Hansen and Landauer, 1958) equipped with a pressure-proofed Schaevitz linear-variable differential transformer. The caliper was triggered at the bottom and drawn up by an electro-mechanical winch at $5-10 \mathrm{~cm} / \mathrm{s}$. Calibration of the caliper was done routinely before and after each run with two known diameters. The diameters for 1977 through 1983 inclusive appear in Figure 1a for the deepest $12 \mathrm{~m}$. This interval has been divided into zones (marked above the top of Figure 1a) by referring to the $\delta\left({ }^{18} \mathrm{O}\right)$ and microparticle concentration $P$ (see Table I).

TABLE I. ZONES OF THE BOTTOM $12 \mathrm{~m} \mathrm{OF} \mathrm{THE} 1977$ AGASSIZ HOLE AS MARKED ON FIGURE la.

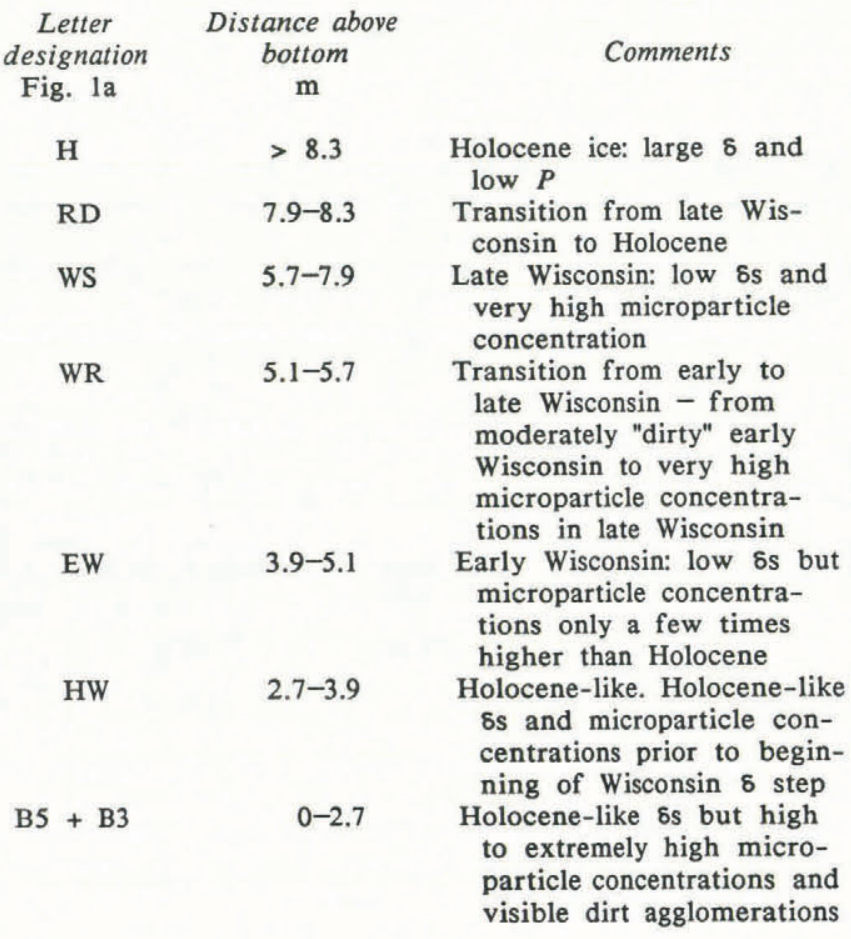

The theory of closure of a cylindrical hole in isotropic ice, as given by Nye (1953) and used in Paterson's (1977) review paper, is followed here.

The average effective strain-rate $\dot{\epsilon}$ operating between times $t_{2}$ and $t_{1}$ changes the bore-hole diameter $a(t)$ and the effective strain-rate is

$$
\dot{\epsilon}=-\ln \left[a\left(t_{2}\right) / a\left(t_{1}\right)\right] /\left(t_{2}-t_{1}\right) .
$$

The effective shear stress $\tau$ is

$$
\tau=-p / n
$$

where the net hydrostatic pressure is $p$ and $n$ is the power in the isotropic Glen-body flow law,

$$
\dot{\boldsymbol{\epsilon}}=A_{0} \exp \left[\frac{-Q}{R T}\right] \tau^{n} .
$$

$Q$ is the activation energy for ice. For temperatures $T \leqslant-10^{\circ} \mathrm{C} \quad\left(44 \leqslant Q \leqslant 62 \times 10^{3} \mathrm{~J} / \mathrm{mol}\right) . \quad R$ is the gas content $8.3143 \mathrm{~J} \mathrm{deg}^{-1} \mathrm{~mol}^{-1}$. Paterson (1977) adopted $Q=$ $54 \mathrm{~kJ} / \mathrm{mol}$. Using this $Q$ value and the empirical relationship, he derived between $\dot{\epsilon}$ and $\tau$ (with $n=3$ ) the non-temperature-sensitive constant $A_{0}$ (closure) = $2.662 \times 10^{3} \quad\left(\mathrm{MN} / \mathrm{m}^{2}\right)^{-3} \mathrm{~s}^{-1} . A_{\mathrm{o}}$ depends mainily on impurities, crystal orientation, and size but it also implicitly 
Fisher and Koerner: Rheological properties of microparticle-laden ice

B B H E W WS RD H
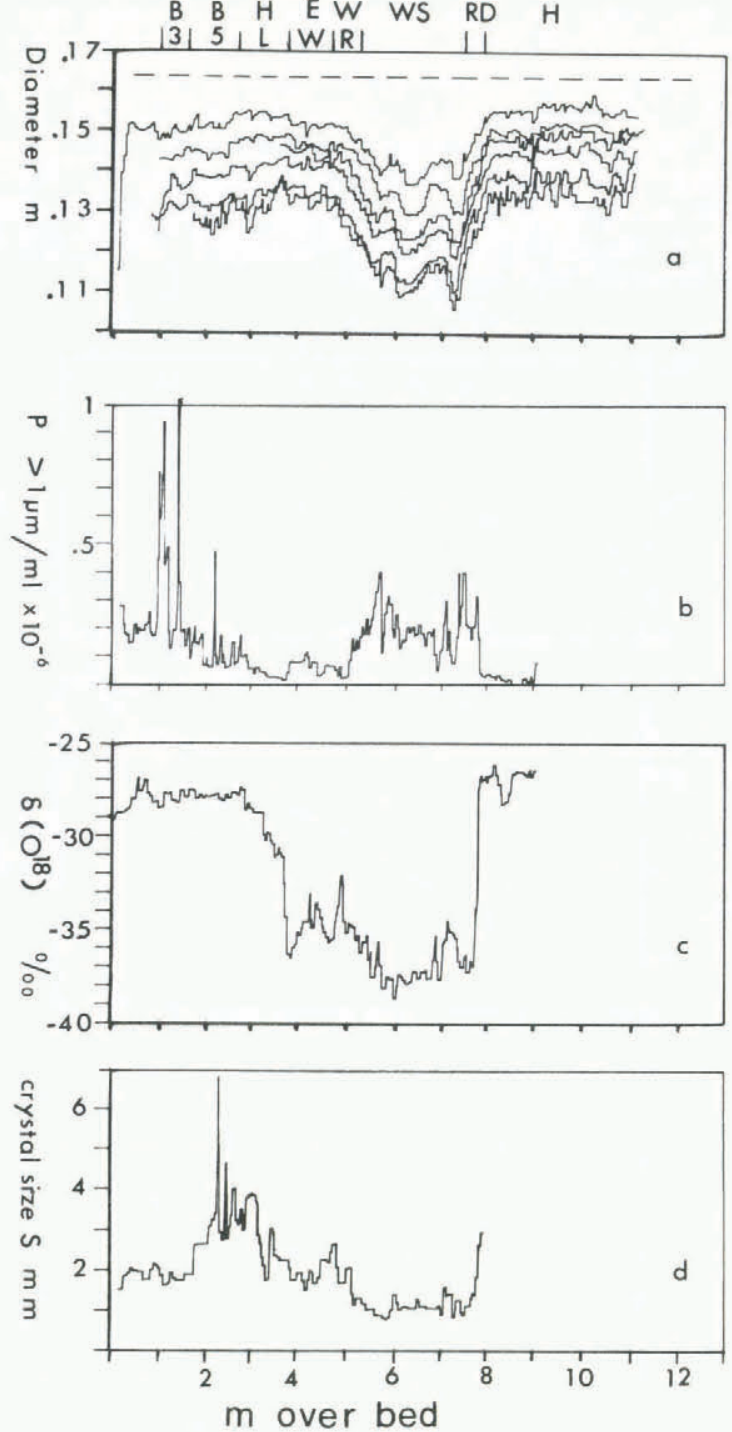

Fig. 1. a. Diameter of the Agassiz 77 bore hole from bedrock to $y=12 \mathrm{~m}$ over bedrock from 1977 (dashed line) every year to 1983. Along the top of this figure are noted the zones referenced in the text and defined in Table I.

b. Microparticle concentration, P, of Agassiz 77 core, number (diameter $\geqslant 1 \mathrm{\mu m}$ ) $/ \mathrm{ml}$.

c. $8\left({ }^{18} \mathrm{O}\right)$, of the bottom $9 \mathrm{~m}$ of Agassiz 77 core.

d. Crystal size $S(\mathrm{~mm})$ of the bottom $8 \mathrm{~m}$ of Agassiz 77 core. These were obtained by counting crystal-boundary intersections of a vertical line on a vertical thin section. To obtain "corrected" crystal sizes, one can multiply $S$ by the factor 1.78 (Hilliard, 1970). Note that we use raw crystal sizes throughout this paper.

e. Calcium concentration in (ppb) parts (mass) $\mathrm{Ca}$ per billion $\left(10^{9}\right)$ of ice (mass). Measurements were made on a flameless (AA) atomic absorption spectrometer, Perkin-Elmer 603. Sample-preparation procedures followed Cragin and others (1977).

f. Sodium concentration in parts per billion $\left(10^{9}\right)$ by mass for the bottom $9 \mathrm{~m}$ of Agassiz 77 core, measured with a Perkin-Elmer $603 \mathrm{AA}$.

g. Conductivity (at $20^{\circ} \mathrm{C}$ ) of liquid samples. Measurements done on a radiometer CDM3.

h. Ice density of selected segments of the Agassiz 77 ice core. They were obtained by measuring air-bubble areas of thin sections and assuming that bubble-free ice has a density of $917 \mathrm{~kg} \mathrm{~m}^{-3}$. Areas were measured on a Metals Research Quantimet image analyser.

$i$. Shear strain-rates over the bottom $12 \mathrm{~m}$ of the Agassiz bore hole measured by bore-hole tilt 6 years after drilling. The dotted line is the theoretical shear strain-rate as explained in the text.
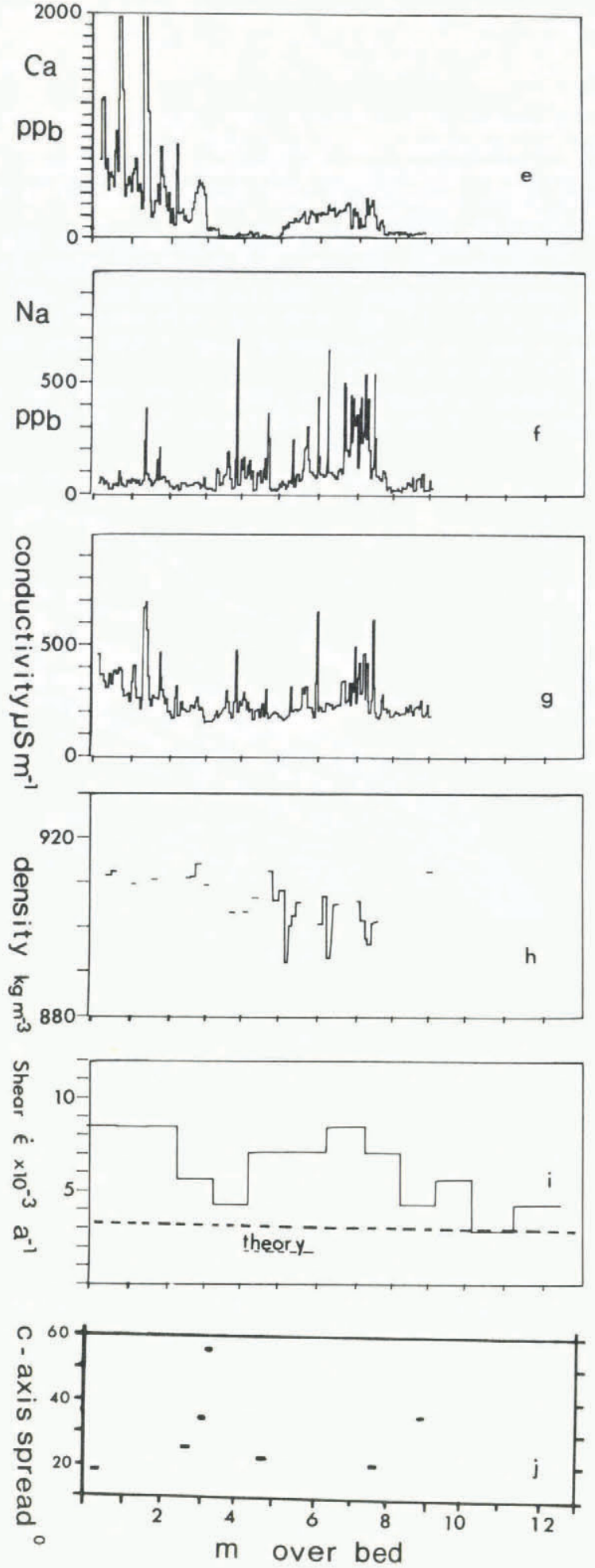

j. Angular spread $(\alpha)$ of the optic or c-axis over the bottom $9 \mathrm{~m}$ of the Agassiz 77 core. This is a measure of half the apex angle of a cone containing $90 \%$ of optic axes of ice crystals in a thin section. At $237 \mathrm{~m}$ depth this angle is $83^{\circ}$, i.e. completely random c-axis distribution. The average direction of the $c$-axis over the bottom $9 \mathrm{~m}$ is $10^{\circ}$ off vertical. This is probably due to bedrock angle which has a value of $17^{\circ}$ averaged over several hundred meters up- and down-stream of the Agassiz 77 hole. 
assumes that the ice is isotropic. Only Glen-body or secondary-type creep is described by Equation (3). To make this explicit, $\dot{\epsilon}_{2}$ will be used henceforth for secondary creep-rate.

Diameters were measured every year over the bottom $12 \mathrm{~m}$ but sometimes with 2 year intervals for the shallower depths. Here the Agassiz 77 diameters were averaged over $20 \mathrm{~cm}$ depth intervals and then further averaged by each zone (Fig. 1a, Table I).

$p$, and hence $\tau$, is calculated knowing the firn-ice density profile, the oil level, and oil density. These are all well known for Agassiz 77 and for the region of particular interest $(0 \leqslant y \leqslant 12 \mathrm{~m}) \quad\left(0.70 \leqslant p \leqslant 0.71 \mathrm{MN} / \mathrm{m}^{2}\right)$. In the same $y$ interval the temperature range is also very narrow $\left(-16.75^{\circ} \geqslant T \geqslant-17.0^{\circ} \mathrm{C}\right)$.

Highest strain-rates were always in the first year, after which some of the total strain curves (Fig. 2) have cycles

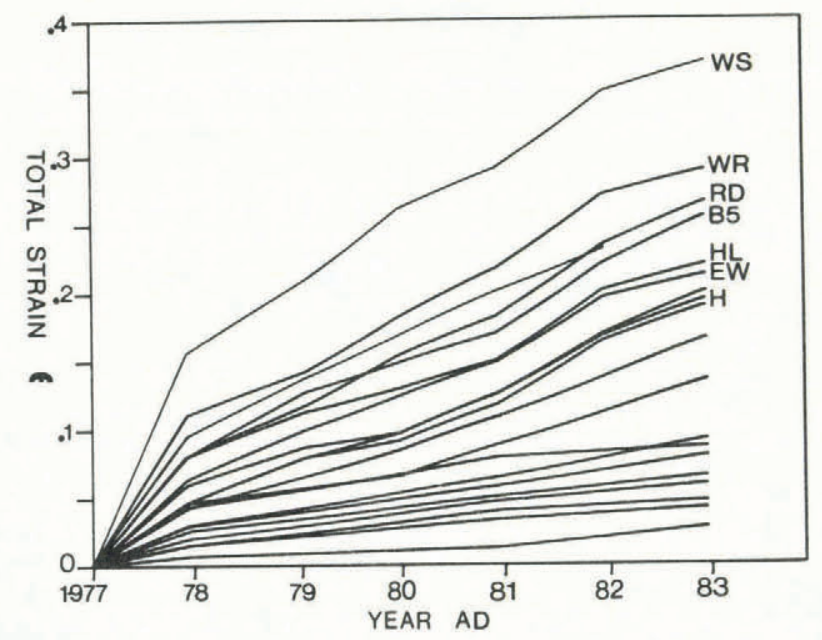

Fig. 2. Total closure strain for various depth zones of the Agassiz 77 bore hole. These zones are noted for the bottom $12 \mathrm{~m}$ and defined in Table $I$ and Figure $1 a$.

of decelerating and accelerating closure strain. Like Paterson's (1977) study, we assume that the first year's strain-rate was mainly transitory or first-order creep denoted $\dot{\epsilon}_{1}$. The subsequent decelerations produce strainrate minima that approach secondary or "Glen-type" creep $\dot{\epsilon}_{2}$, and further accelerations produce maximum strain-rates that are assumed to approach tertiary or recrystallization creep, $\dot{\epsilon}_{3}$ (Paterson, 1977). An example of $\dot{\epsilon}_{3}$ creep is the 1981-82 creep for the Wisconsin (WS) ice (Fig. 2).

In practice, the strain-rates, types $\dot{\epsilon}_{1}, \dot{\epsilon}_{2}, \dot{\epsilon}_{3}$, were assigned using two independent methods:

(i) The minimum-maximum method used by Paterson (1977);

(ii) Statistical partition.

(i) Minimum-maximum method to determine creep types

The minimum-maximum method has been described in Paterson (1977). The only difference from Paterson's procedure is that, because of the continuity and long duration of this study, multiple minima $\dot{\epsilon}_{2}$ and maxima $\dot{\epsilon}_{3}$ are available for some of the curves of Figure 2, e.g. for the microparticle-rich Wisconsin ice. For shallower curves (unlettered Holocene curves below $\mathbf{H}$ in Figure 2), minima had not been reached by 1983 .

The first year's strain-rates are denoted $\dot{\epsilon}_{1}$, the average minimum (or secondary) strain-rates $\dot{\epsilon}_{2}$, and average maximum (tertiary) strain-rates $\dot{\epsilon}_{3}$. The averages for each zone are plotted for each type of creep versus microparticle concentration $P$ (Fig. 3). The solid lines are least-squares fits to these points. The dashed lines are obtained if the statistical partition method is used to separate strain types.

For all types of creep in the deepest $12 \mathrm{~m}$ of the hole, there is a significant tendency for the microparticle-laden, late Wisconsin ice (WS) to deform the fastest and the relatively clean Holocene ice $(\mathrm{H})$ the slowest. The data for B3 and deeper is excluded from Figure 3 because the large number of microparticles $P$ shown in Figure $1 \mathrm{~b}$ for $y<1.5 \mathrm{~m}$ are from visible agglomerations, and do not represent the uniform microparticle content in the ice matrix as does $P$ for $y>1.5 \mathrm{~m}$. Similar agglomerations occur in the bottom $0.8 \mathrm{~m}$ of the Devon Island Ice Cap cores (Koerner and Fisher, 1979).
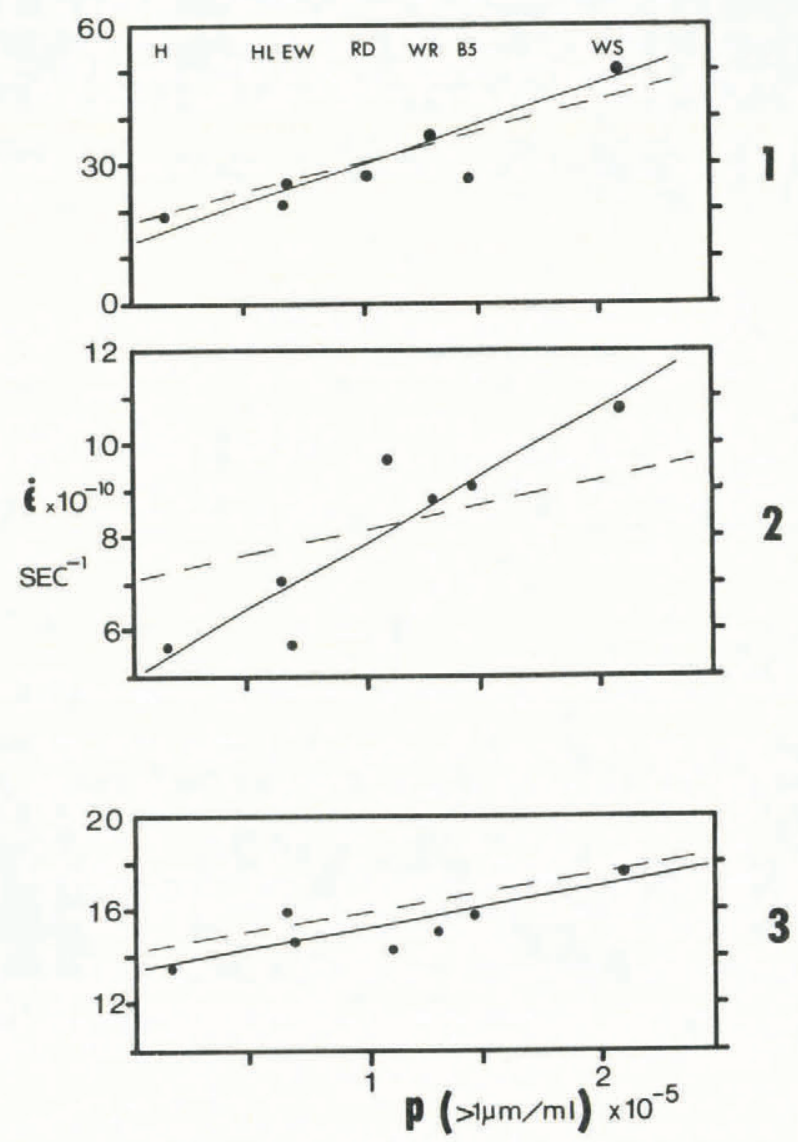

Fig. 3. Three kinds of closure strain-rates versus microparticle content. The points are for the zones denoted along the top of the figure and defined in Table I. These strain-rate types have been decided on by the minimum-maximum procedure described in the text.

$a . \dot{\epsilon}_{1}$ is the first-year or transitory strain-rate.

b. $\dot{\epsilon}_{2}$ is the minimum of Glen-body strain-rate.

3. $\dot{\epsilon}_{3}$ is the maximum or tertiary strain-rate.

The solid line is a least-squares fit to the points and the dashed line is a least-squares fit through the data when the strain-rate types are decided by the statistical partition method described in the text.

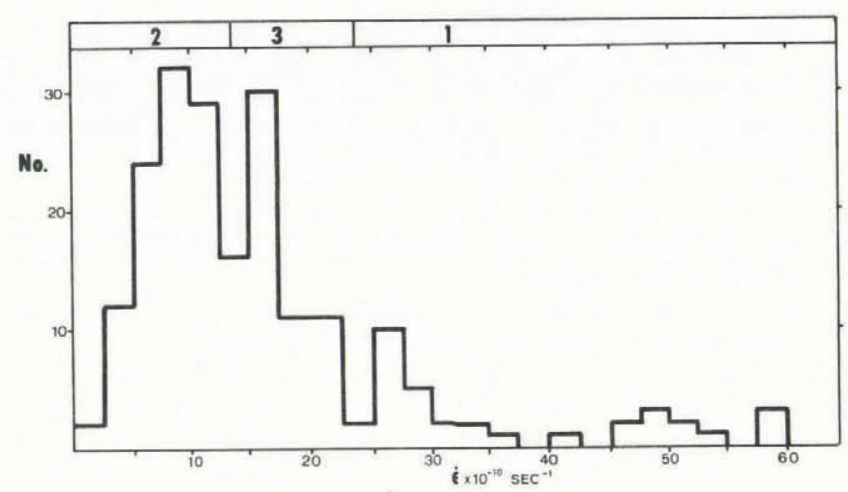

Fig. 4. The closure strain-rate distribution using all the strain-rate data 1977-83 averaged on $20 \mathrm{~cm}$ depth increments. The three strain-rate types are marked across the top and are defined by the minima in the distribution. 
(ii) The statistical partition method for obtaining creep types The second method partitions all the $20 \mathrm{~cm}$ average strain-rates for all the year intervals into a population distribution (Fig. 4). Figure 4 shows three distinct peaks in the $\dot{\epsilon}$ distribution and the three regions shown can be picked using the minima of the population. These regions are

$$
\begin{aligned}
0<\dot{\epsilon}_{2} & \leqslant 14 \times 10^{-10} \mathrm{~s}^{-1}, \\
14<\dot{\epsilon}_{3} & \leqslant 23 \times 10^{-10} \mathrm{~s}^{-1}, \\
\dot{\epsilon}_{1} & >23 \times 10^{-10} \mathrm{~s}^{-1} .
\end{aligned}
$$

With these defined as strain-rate categories for $\dot{\epsilon}_{1}, \dot{\epsilon}_{2}$, and $\dot{\epsilon}_{3}$, all the strain-rates can be sorted and plotted against the appropriate $20 \mathrm{~cm}$ average microparticle concentrations $P$ (Fig. 5a, b, and c). The solid lines on Figure 5 are leastsquares fits. These lines appear also in Figure 3 (as the dashed lines).

From Figure 3 one can see that the two methods for separating strain-rate types produce very similar regression
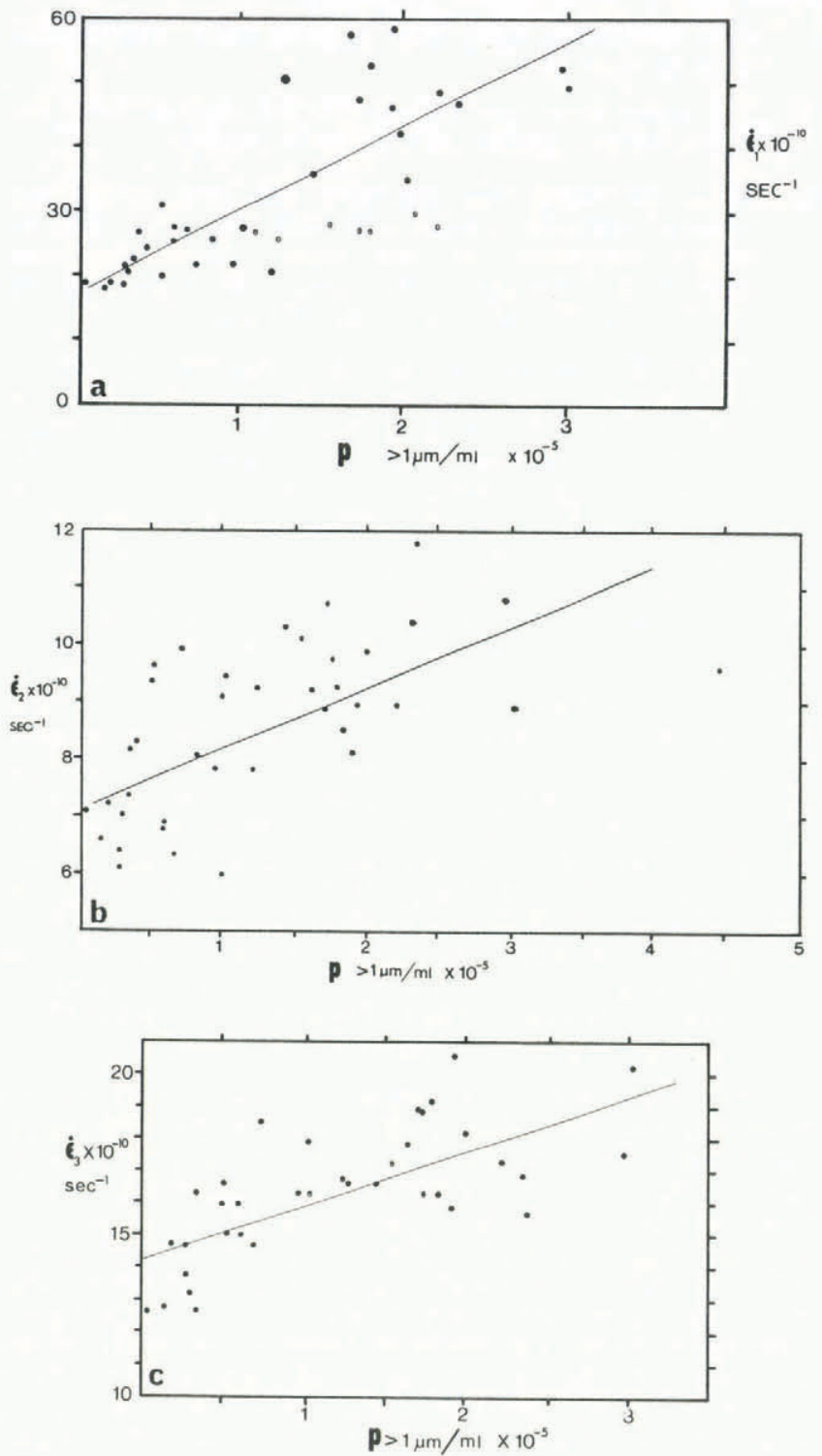

Fig. 5. Three types of closure strain-rate as found using the statistical partition procedure. The points are the $20 \mathrm{~cm}$ averages of strain-rate plotted against microparticle concentration $P$. The open circles are for ice containing visible agglomerations of dirt. These open-circle points are not used in forming the least-squares lines that appear.

a. Transitory-type strain-rate $\dot{\epsilon}_{1}$

b. Glen-type strain-rate $\dot{\epsilon}_{2}$

c. Tertiary-type strain-rate $\dot{\epsilon}_{3}$. lines against microparticles for $\dot{\epsilon}_{1}$ and $\dot{\epsilon}_{3}$ creep. However, the slope of $\dot{\epsilon}_{2}$ versus $P$ from the minimum-maximum method is steeper than from the statistical partition method (Fig. 3b). Since the partitition method uses all the $\dot{\epsilon}_{i}$ data and not just the extreme values, one might expect some of the derived $\dot{\epsilon}_{2}$ values to include examples of mixed mode creep, i.e. $\left(\dot{\epsilon}_{1}+\dot{\epsilon}_{2}\right)$ of $\left(\dot{\epsilon}_{2}+\dot{\epsilon}_{3}\right)$.

Paterson (1977) summarized $\dot{\epsilon}_{2}$ closure strain-rate data from Arctic and Antarctic holes by converting the strainrates to a common temperature of $-22^{\circ} \mathrm{C}$ using an activation energy of $Q=54 \mathrm{~kJ} / \mathrm{mol}$. In order to compare directly with his work (Paterson, 1977, fig. 5), we used the same $Q$ value here.

Paterson's $\log \left(\dot{\epsilon}_{2}\right)$ versus $\log (\tau)$ plot for all previous bore-hole closure measurements has a regression line (at $T=$ $-22^{\circ} \mathrm{C}$ ) that gives

$$
\dot{\epsilon}_{2}=1.27 \times 10^{-8} \tau^{2.7}
$$

with $\dot{\epsilon}_{2}$ in $\mathrm{s}^{-1}$ and $\tau$ in $\mathrm{MN} / \mathrm{m}^{2}$. This line is reproduced in Figure 6 along with the Agassiz 77 hole $\dot{\epsilon}_{2}$ data $(0<y<12 \mathrm{~m})$ shifted to $-22^{8} \mathrm{C}$ for each zone. The Holocene points $(\mathrm{H})$ fit the Paterson line but the older parts of the hole close significantly faster with the dirtiest part of late Wisconsin (WS) having closure strain-rates nearly three times the Holocene values, $\mathrm{H}$.

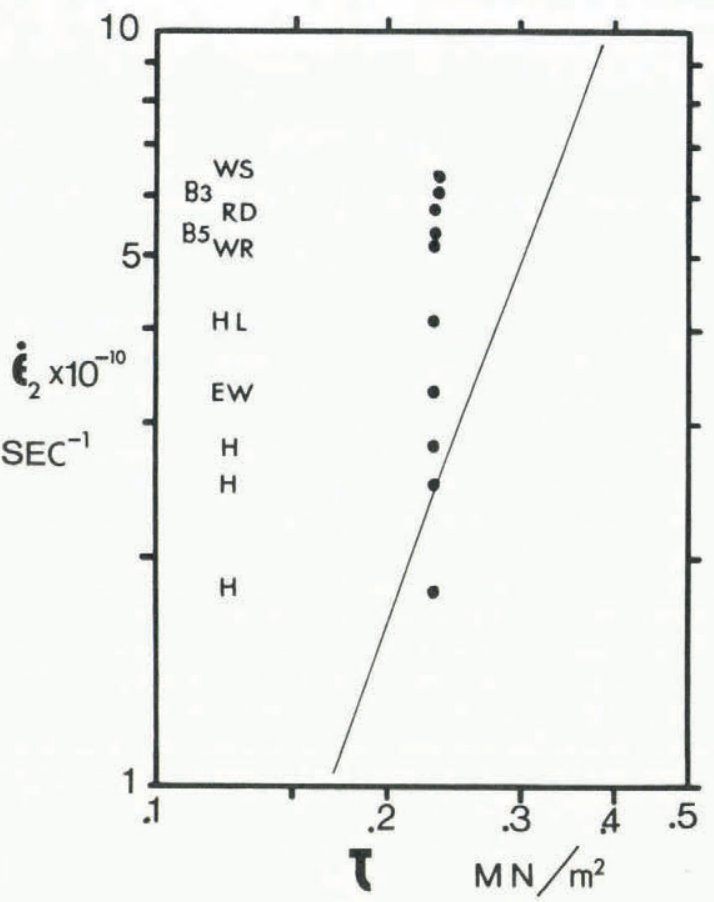

Fig. 6. Logarithmic plot of minimum or Glen-type $\dot{\epsilon}^{2}$ closure strain-rates for the zones in the bottom $13 \mathrm{~m}$ of the Agassiz 77 hole versus effective stress $\tau$. The zones are as in Table I and Figure 1a. The measured strain-rates have been shifted to $-22^{\circ} \mathrm{C}$ to be directly comparable with Paterson's (1977, fig. 5) empirical line for $\dot{\epsilon}_{2}$ versus $\tau$ from non-ice-age zones of other bore holes.

Ice in the $0<y<12 \mathrm{~m}$ range has a highly concentrated $c$-axis alignment about $10^{\circ}$ off vertical. The $c$-axis concentration $\alpha$ as expressed in Figure $1 \mathrm{j}$ is half the apex angle of the cone that contains $90 \%$ of the measured optic axes. The definition of $\alpha$ is the same as used by Herron and others (1985). This concentration favours shear deformation and tends to hinder bore-hole closure (Thwaites and others, 1984). There is little variation in the $c$-axis alignment in the bottom $12 \mathrm{~m}$ (Fig. 1j) and the enhanced closure for ice with a high microparticle content is not evidently reflected in variations in $c$-axis. This was also the case for the Devon Island Ice Cap cores. Of course, the value of $A_{0}$ in Equation (3) can be increased by increasing the $c$-axis alignment and this has been called $c$-axis enhancement (Shoji and Langway, 1984). 
The $A_{0}$ enhancement in the microparticle-rich preHolocene ice which is not due to variations in $c$-axis fabric we call rheological enhancement. Shoji and Langway (1984), from laboratory testing of natural ice, have separated $c$-axis enhancement (fabric factor) from rheological enhancement (remnant or impurity factor). Their impurity factors for Wisconsin ice are in the range from 3 to 6 . Also, Reeh and others (1985) and Dahl-Jensen (1985) have reported rheological enhancement in the 3-4 range from the Dye 3, Greenland, bore hole.

Bore-hole closure strains are "unnatural" in that the bore hole was suddenly and arbitrarily put there. The closure is consequently not along favourably aligned planes. Also, the effective stresses in closure situations tend to be considerably larger than those usually encountered in the slow undisturbed creep of ice. In addition, since the total strains and even crystallographic alignment and creep type are functions of radial distance from the centre of the hole and time since drilling, the actual meaning of the measured strain-rate at the hole's wall is not clear. Nevertheless, since the enhancements we obtained from closure are relative and from a narrow depth range, we feel they are real.

\section{BORE-HOLE TILT}

If a site is over four times the ice thickness (Paterson, 1981) from the divide, then one can approximate ice deformation by a simple shear model (Nye, 1952). If the $x$ coordinate is measured in the direction of flow, the shear stress at depth $Z$ is

$$
\tau_{x z}=\rho g \alpha_{s} Z
$$

and this shear stress is related to the shear strain-rate by

$$
\dot{\epsilon}_{x z}=A \tau_{x z}^{n}
$$

with $\alpha_{\mathrm{S}}$ the surface slope (assumed small), $\rho$ the density of ice, and $g$ the acceleration due to gravity. We take $n=3$. $A=A_{0} \exp (-Q / R T)$ as in Equation (3) where $A_{0}$ (tilt), the temperature-independent factor, is $4.2919 \times 10^{5}$ $\left(\mathrm{MN} / \mathrm{m}^{2}\right)^{-3} \mathrm{~s}^{-1}$ or $\left(1.35 \times 10^{-5} \mathrm{~Pa}^{-3} \mathrm{a}^{-1}\right)$. This value for $A_{0}$ is derived from the recommended cold-ice activation energy $Q=60 \mathrm{~kJ} / \mathrm{mol}$ and Paterson's recommended value for $A$ for polycrystalline ice at $T=-10^{\circ} \mathrm{C}$ (i.e. $A=5.2 \times 10^{-7}$ $\left(\mathrm{MN} / \mathrm{m}^{2}\right)^{-3} \mathrm{~s}^{-1}$ (Paterson, 1981). The simple shear model, Equations (4) and (5), works at sites like Dye 3, Greenland, which is about ten times the ice thickness from the divide, but it should not be used for a site like the Agassiz 77 bore hole which is only four thicknesses from the divide. Under such circumstances, the longitudinal strain-rate $\dot{\epsilon}_{x x}$ must be included and deformation can be estimated by (Nye, 1959) the equations

$$
\begin{gathered}
\dot{\epsilon}=A \tau^{n} \\
\rho g \alpha_{s} Z=\tau\left(\dot{\epsilon}^{2}-\dot{\epsilon}_{X X}^{2}\right)^{1 / 2} / \dot{\epsilon}
\end{gathered}
$$

with the effective strain-rate $\dot{\epsilon}$ here given by

$$
\dot{\epsilon}^{2}=\dot{\epsilon}_{x z}^{2}+\dot{\epsilon}_{x x}^{2} .
$$

In practice, $\dot{\epsilon}_{x x}$ is estimated and Equations (6) and (7) are solved for $\dot{\epsilon} x z$ at a given ice depth $Z$ (and temperature) by iteration on $\hat{\epsilon}$, e.g. Paterson, 1983.

The tilting rate $y$ of an initially vertical bore hole is equal to twice the shear strain-rate $\dot{\epsilon}_{x z}$ and is approximated by (Paterson, 1983)

$$
\dot{y}=2 \dot{\epsilon}_{x z}=\frac{\partial u}{\partial Z}
$$

where $u$ is the $x$ component of velocity. Equations (4) through (7) assume that the ice is isotropic.

Tilting rates and subsequent shear strain-rates can be measured by logging the inclination of bore holes. When the inclinations are small,

$$
y=\frac{y_{x}^{*}-y_{x}}{\Delta t}
$$

where $\gamma_{x}$ is the initial inclination (in radians) and $\gamma_{x}^{*}$ after time $\Delta t$.

Four angular inclination surveys of the Agassiz 77 hole have been made. Immediately after drilling in 1977 and again in 1979, the hole was logged under contract with Eastman Oil Well Survey Co. Limited and Sperry-Sun of Canada Limited, respectively. The long $4 \mathrm{~m}$ tool apparently only penetrated to $328 \mathrm{~m}$ in 1977 and to $322 \mathrm{~m}$ in 1979 , although the hole is $338 \mathrm{~m}$ deep, and there was no geometric reason for failure to reach the bed. The 1977 survey showed that the hole was initially everywhere within $\frac{1}{2}^{\circ}$ of vertical.

In 1982 and 1983, we conducted our own inclination surveys using a Pajari inclinometer (Pajari Instruments Ltd of Canada) mounted on a $1 \mathrm{~m}$ long tool. The two earlier surveys used battery-powered gyros to give angular inclinations to $1^{\prime}$ and azimuth to $1^{8}$. The Pajari instrument is a self-locking pendulum and magnetic compass device that gives azimuths and inclinations to $1^{\circ}$. The limiting factors in all these surveys tended to be the spring-centering accuracy and depth measurement. So, while the Pajari surveys only gave angles to $1^{\circ}$, we feel these inclination results are the more reliable because:

i. The inclinations were done 6 years after drilling and were as large as $6^{\circ}$.

ii. The azimuths of the surface velocity derived from the Pajari surveys agreed with the 1979 survey.

iii. While the Pajari tool was only $1 \mathrm{~m}$ long (giving the required resolution), many runs each year were done to ensure repeatability at each depth. Runs were also done with a $2 \mathrm{~m}$ tool. No repeat runs were made in the 1977 or 1979 surveys of the 77 hole.

iv. The Pajari surveys unequivocally reached bedrock as the bottom had previously been marked on the inclinometer cable using a very narrow weight which allowed the observer to feel the weight change on the cable when bedrock was reached. All depth/inclinometer measurements were then made with reference to the bed and not the surface. Contrasting with this method, the 1977 and 1979 contract surveys measured depth from the surface using cable-length friction counters attached to an oily cable; slippage almost certainly occurred. The contract surveys therefore reached bedrock but gave incorrect depths. The alternative explanation that both 1977 and 1979 survey tools jammed in the hole before reaching bedrock is unlikely. There is no reason for jamming in 1977 as the hole had just been drilled, was within $\frac{1}{2}$ of vertical (drill-mounted Pajari measurements during drilling attested to this), and was everywhere $16.5 \mathrm{~cm}$ in diameter. The only location for jamming to have occurred during the 1979 survey was at the Wisconsin/Holocene transition where hole curvature reached maximum values. However, this transition is $8 \mathrm{~m}$ above the bed and not the $16 \mathrm{~m}$ reported.

The shear strain-rates derived from the contract surveys agree well with the Pajari results except in the depth range 280-310 m, where the contract strain-rates are three times larger. If, as we believe, the commercial depth measurements were in error, and both the 1977 and 1979 surveys actually reached bedrock, then the different shear strain-rate sets are everywhere in reasonable agreement. For all these reasons, we adjusted the contract survey depths assuming that they actually reach bedrock. The Pajari results are used from $Z=312$ to $338 \mathrm{~m}$ and the contract results from 0 to $310 \mathrm{~m}$. Figure 7 summarizes all the shear or tilt strain-rate measurements and Figure li details the bottom $12 \mathrm{~m}$.

Estimates of theoretical tilt strain-rates $\dot{\epsilon}_{x z}$ were made using Equations (6) and (7) and the following approximation to the longitudinal strain-rate.

$\dot{\epsilon}_{x x}= \begin{cases}1.43 \times 10^{-4} & \text { for }\left(0 \leqslant Z_{\text {ice }}<208 \mathrm{~m}\right) \mathrm{a}^{-1} \\ 1.43 \times 10^{-4}+ & \left.0.2435 \times 10^{-4}\right)(Z-208)\end{cases}$

for $\left(Z_{\text {ice }} \geqslant 208 \mathrm{~m}\right) \mathrm{a}^{-1}$ 


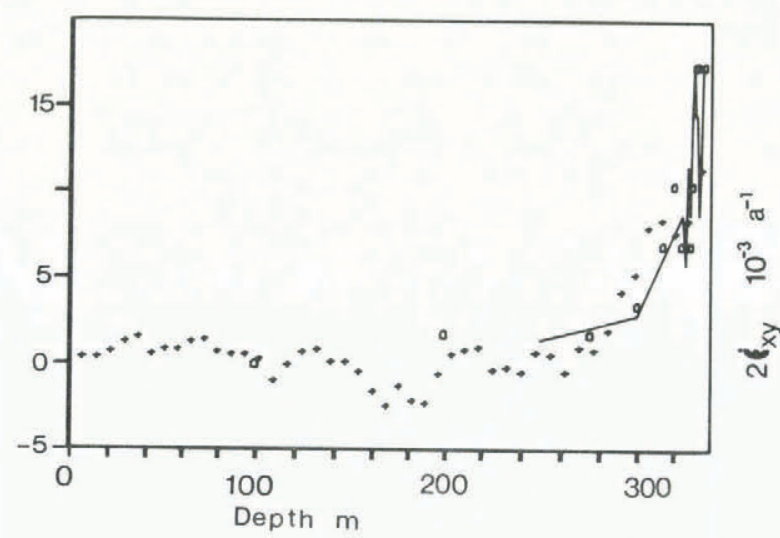

Fig. 7. Tilt or two times the shear strain-rate of the Agassiz 77 bore hole verus real depth: crosses are values from a "professional" survey made in 1978; open circles are from the Pajari survey of 1982; and the line is from the Pajari survey of 1983.

where $x$ is distance down the flow line and $Z$ is iceequivalent depth. This two-line approximation for $\dot{\epsilon}_{x x}$ is based on

i. A measured surface value $\left(\dot{\epsilon}_{x x}\right)_{\mathrm{s}}=1.43 \times 10^{-4} \mathrm{a}^{-1}$.

ii. A depth-averaged value $\left\langle\dot{\epsilon}_{x x}\right\rangle=\frac{\partial \bar{u}}{\partial x}-\frac{u_{s}}{H} \frac{\partial Z_{s}}{\partial x}$

$$
=6.31 \times 10^{-4} \mathrm{a}^{-1}
$$

where $\bar{u}$ is the ice-depth averaged velocity $\left(0.38 \mathrm{~m} \mathrm{a}^{-1}\right)$, $u_{\mathrm{s}}$ the surface velocity $\left(0.45 \mathrm{~m} \mathrm{a}^{-1}\right), H$ the thickness in ice equivalent $(321 \mathrm{~m})$, and $\partial Z_{\mathrm{s}} / \partial x$ the surface slope $(0.021 \mathrm{rad})$.

iii. An estimate of $\dot{\epsilon}_{x x}$ near the bed, at $Z_{\text {ice }}=313 \mathrm{~m}$.

$\left(\dot{\epsilon}_{x x}\right)_{\mathrm{b}}=-\left[\frac{\partial u}{\partial Z}\right]_{\mathrm{b}}\left[\frac{\partial Z}{\partial x}\right]_{\mathrm{b}}=27.1 \times 10^{-4} \mathrm{a}^{-1}$

where $(\partial u / \partial Z)_{b}=-8.73 \times 10^{-3} \mathrm{a}^{-1}$ comes from the inclination measurements and the bottom slope averaged over $900 \mathrm{~m}$ of flow line is $(\partial Z / \partial x)_{\mathrm{b}}=0.31 \mathrm{rad}$.

With these theoretical estimates of $\dot{\epsilon}_{x z}$, the ratios $\left(\dot{\epsilon}_{x z}\right.$ measured $/ \dot{\epsilon}_{x z}$ theory) are calculated and taken to be ( $A_{\mathrm{o}}$ measured $/ A_{\mathrm{o}}$ theory), a measure of the shearenhancement factors (SEF).

Well above the Wisconsin ice at $Z_{\text {ice }}=280$, we calculate $\operatorname{SEF}=1.0$. Figure $8 \mathrm{~b}$ gives $\mathrm{SEF}$ over the bottom $12 \mathrm{~m}$. The Holocene ice has an SEF near 1 and the largest SEF of 3 occurs in the late Wisconsin ice. The Holocene SEFs of 1 seem to indicate little influence of $c$-axis concentration which shows a gradual strengthening of fabric with increasing depth in the Holocene ice.

\section{COMPARISON OF TILT- AND CLOSURE-DERIVED ENHANCEMENT FACTORS WITH OTHER VARIABLES}

Enhancement factors for secondary type strain-rates $\dot{\epsilon}_{2}$ derived from the bore-hole closure measurements are found for each zone of Figure la. The "normal" or theoretical $\dot{\epsilon}_{2}$ values come from Patersons's empirical line reproduced in Figure 6. The resulting closure-enhancement factors, CEFs, over the bottom $12 \mathrm{~m}$ of the Agassiz 77 hole are shown in Figure $8 \mathrm{a}$ along with the tilt-derived shear strain-rate enhancement factors, SEFs in Figure $8 \mathrm{~b}$. The two curves of Figure 8 are remarkably similar, with two broad enhancedflow maxima at $0-2 \mathrm{~m}$ over the bed (zones B3, B5, and deeper) and between 4.5 and $8.0 \mathrm{~m}$ over the bed (zones $W R$, WS, and RD, i.e. late Wisconsin ice). The WS or late
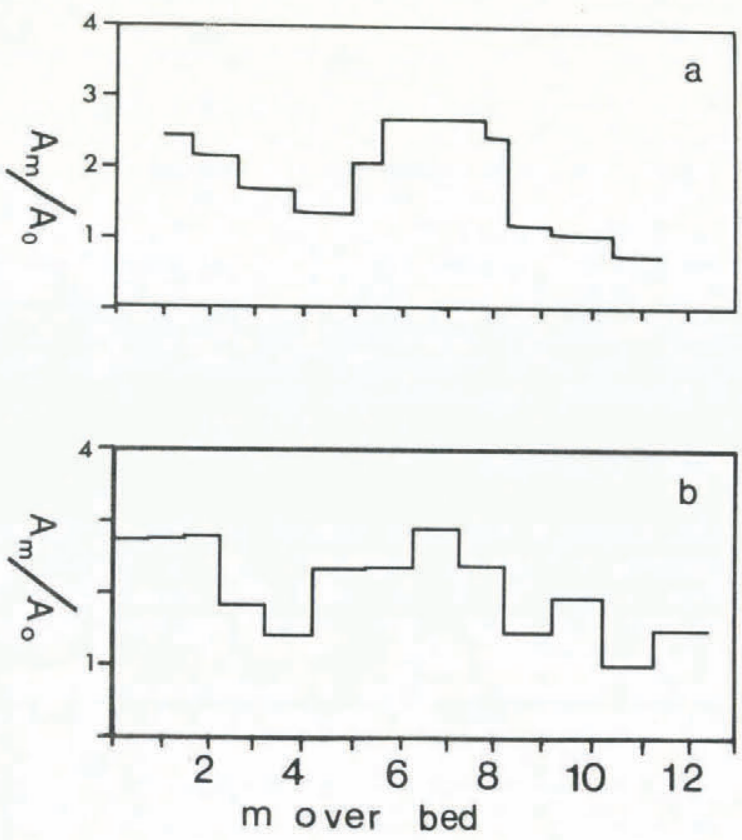

Fig. 8. Enhancement factors (measured creep/theoretical or expected creep) for (a) closure strain-rates, i.e. closure-enhancement factor or CEF; (b) shear or tilt strain-rates, i.e. shear-enhancement factor SEF.

Wisconsin ice has the largest SEF and CEF. Comparison of the flow-enhancement factor plots of Figure 8 with other measurements allows elimination of some possible causal variables.

\section{c-AXIS ALIGNMENT}

For the Holocene ice just above the Wisconsin in $(12>y>8 \mathrm{~m}), \mathrm{SEF}=1.5$ with $\alpha=35^{\circ}$ and for shallower Holocene ice (e.g. $y \sim 44 \mathrm{~m}$ ), SEF $=1.0$ and $\alpha=85^{\circ}$. Evidently, the SEF changes are not strongly dependent on $\alpha$. This conclusion seems to substantiate that of Dahl-Jensen (1985) from Dye 3 data, and Russell-Head and Budd (1979) from the Law Dome study. Furthermore, the variations in SEF between 0 and $8 \mathrm{~m}$ over the bed can have little to do with $c$-axis alignment. Crystal $c$-axis measurements of seven thin sections show that the $c$-axis fabric is very strong and quite stable for the interval $0-10 \mathrm{~m}$ over the bed (Fig. $1 \mathrm{j}$ ). There are four narrow bands of very large crystals $4 \mathrm{~mm}$ or larger $2<y<3.5 \mathrm{~m}$ over the bed. Three of the bands are less than $10 \mathrm{~cm}$ thick but contain crystals up to $7 \mathrm{~mm}$ Two sections that include some of these very narrow bands have $c$-axis concentrations typical of the rest of the bottom $12 \mathrm{~m}$. The fourth band is about $30 \mathrm{~cm}$ thick and the thin section from it had a $90 \% c$-axis containment cone with a half-angle of $73^{\circ}$ ! However, because of their size, there were too few crystals in this band to allow much significance to be placed on this $\alpha$ value.

If the late Wisconsin (WS) SEF maximum was due mainly to $c$-axis concentration, then the closure rates should have a minimum there because shear tilting and closure cannot utilize the same easy glide planes (Thwaites and others, 1984). In fact, the opposite is true (Fig. 8).

Similarly, in the Devon Island Ice Cap and Dye 3 cores, there is little change in the $c$-axis fabric from early Holocene to late Wisconsin ice but there is a large enhancement-factor change (Paterson, 1977; Dahl-Jensen, 1985; Herron and others, 1985).

$8\left({ }^{18} O\right)$

Large enhancements are not only associated with very negative (ice-age) $\delta\left({ }^{18} \mathrm{O}\right.$ ) values (Fig. 1c). The bottom $2 \mathrm{~m}$ of ice has large SEFs and CEFs but relatively positive 


\section{DENSITY}

Hooke (1973) noted that enhanced tilting in the Wisconsin ice of the Barnes Ice Cap occurs in ice that is very bubbly and consequently has low density $\left(870 \mathrm{~kg} \mathrm{~m}^{-3}\right)$. Budd (1969) has suggested such low-density ice is weaker. This explanation cannot be used for the Agassiz Ice Cap data, because the densities for one of enhancement maxima (the late Wisconsin zone WS) is only marginally lower $\left(900 \mathrm{~kg} / \mathrm{m}^{3}\right)$ than the surrounding ice $\left(910 \mathrm{~kg} / \mathrm{m}^{3}\right)$. The density for the other enhancement maximum (bottom $2 \mathrm{~m}$ of ice) is completely typical (see Fig. lh).

\section{IMPURITY CONTENT}

The measured impurities include $\mathrm{Na}, \mathrm{Ca}, P$ (insoluble microparticles $>1 \mu \mathrm{m}$ in diameter), and $\sigma$ (liquid conductivity) (Fig. If, e, b, and g), respectively. The conductivity measures the total soluble impurity: salts + acids (Hammer, 1977).

Because calcium is clearly a significant constituent of the microparticles, we can simply refer to the microparticles (Cragin and others, 1977; Boutron, 1979). By comparing the enhancement factors of Figure 8 with the impurity content, one sees that the enhancement does not follow either the total soluble-ion concentration or the $\mathrm{Na}$ whereas it does correlate well with the microparticles. Thus, of the variables measured, we are left with microparticles as being most closely connected statistically to enhancement factors. Gundestrup and Hansen (1984) found a similar correlation between tilt and microparticles in the Dye 3, Greenland, bore hole (see Fig. 10).

The high microparticle mass contains a large calcium contribution (Fig. 1c). This is also true for the Dye 3 core and has been used by Hammer and others (1985) to explain the alkaline nature of these parts of the core from Dye 3. The (ECM) solid conductivity is very low for this ice (Hammer and others, 1985) and Hammer (personal communication) believes that this is a key element in explaining the enhancement-factor profiles.

\section{CRYSTAL SIZE}

The Agassiz 77 crystal size (Fig. 1d) has a marked relationship to microparticle content (Fig. 1b), with high microparticle concentrations in ice with small equant crystals. The same relationship exists for the Devon Island Ice Cap cores (Koerner and Fisher, 1979). Figure 9 shows $\ln \left(S / S^{*}\right)$ plotted against $\ln \left(P / P^{*}\right)$ where $S$ is the uncorrected crystal diameter $(\mathrm{mm})$ and $P$ is the microparticle concentration (number $>1 \mu \mathrm{m} / \mathrm{ml}$ ). $S^{*}$ is the minimum $S(1 \mathrm{~mm}$ ) and $P^{*}$ is the minimum $P(8000 / \mathrm{ml})$. The points use $20 \mathrm{~cm}$ averages of $S$ and $P$ for the bottom $8 \mathrm{~m}$ of ice. Crosses show Agassiz 77 and solid circles the Devon Island Ice Cap cores. The open circles and circled dots are points for the bottom $2 \mathrm{~m}$ and $1 \mathrm{~m}$ of the Agassiz Ice Cap and Devon Island Ice Cap, respectively. This ice contained the agglomerations of visible particles that give rise to the very high $P$ peaks that make the $20 \mathrm{~cm}$ averages unusable. We feel it is the microparticles uniformly distributed in the ice that are important here.

The two lines in Figure 9 are least-squares lines that excluded the circle points. The low-dirt region line is

$$
\ln \left(\frac{S}{S^{*}}\right)=1.94-0.77 \ln \left(\frac{P}{P^{*}}\right)
$$

for $15000<P<36000(>1 \mu \mathrm{m} / \mathrm{ml})$ and for "dirty" ice

$$
\ln \left(\frac{S}{S^{*}}\right)=1.55-0.42 \ln \left(\frac{P}{P^{*}}\right)
$$

for $36000 \leqslant P(>1 \mu \mathrm{m} / \mathrm{ml})$.

The version of Equations (10) and (11) in Koerner and Fisher (1979) is incorrect due to a printing error.

The Devon Island late Wisconsin ice also has a large (>3) closure enhancement (Paterson, 1977), where there is

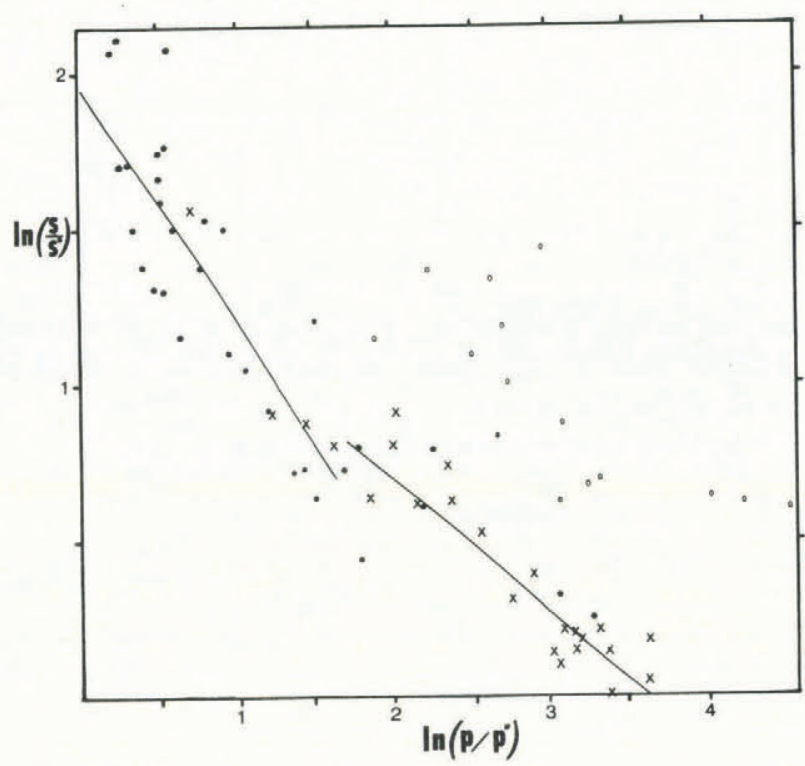

Fig. 9. Natural logarithmic plot of crystal size (uncorrected) $S$ versus microparticle concentration $P$ for the bottom $8 \mathrm{~m}$ of the Agassiz 77 core (crosses) and Devon Island Ice Cap cores (solid circles). The open circles are in the bottom 1.5 and $0.8 \mathrm{~m}$, respectively, of Agassiz 77 and Devon Island ice that contained visible dirt agglomerations. These points were not used to calculate the two least-squares lines shown. $S^{*}$ is the smallest crystal found. $S^{*}=1 \mathrm{~mm}$ and $P^{*}$ is the minimum dirt concentration. $\quad P^{*}=8000$ (number with diameter $\geqslant 1 \mu \mathrm{m} / \mathrm{ml}$ ). It would seem that below a certain threshold of about $P=15000$ there is no relationship between $P$ and $S$.

high microparticle concentration and small crystals but no change in $c$-axis alignment (Koerner and Fisher, 1979). For $P \leqslant 15000$, there appears to be no relationship at all between crystal size and microparticle concentration. This might explain why the cleaner Antarctic ice (Thompson, 1977) shows little or no correlation between crystal size and microparticles.

DYE 3: TILT ENHANCEMENT, MICROPARTICLES, AND ICE CRYSTALS

The Dye 3 bore-hole measurements (Gundestrup and Hansen, 1984) were used to calculate shear strain-rates $\dot{\epsilon}_{x z}$ using Equation (9). The expected or theoretical $\dot{\epsilon}_{x z}$ values were calculated using Equations (4) and (5) with $\alpha_{S}=0.00480 \mathrm{rad}$ (Gundestrup and Hansen, 1984) and with $A_{0}$ and $Q$ equal to the Agassiz Ice Cap shear values. The enhancement ratio, as before, is (measured/theoretical) and is denoted $A_{\mathrm{m}} / A_{0}, A_{\mathrm{m}}$ being the "measured" value of the $A_{0}$ constant.

The measured shear strain-rates (Gundestrup and Hansen, 1984), enhancement factor, microparticle mass (Hammer and others, 1985), and crystal size (Herron and others, 1985) appear in Figure 10. Virtually the same enhancement-factor profile was obtained independently by Dahl-Jensen (1985). The Dye 3 enhancement, microparticle concentration, and crystal size (Fig. 10) bear the same relationship to each other as they do in the Agassiz 77 and Devon Island cores. The Dye 3 late Wisconsin SEF maximum of 3.5 is somewhat larger than the Agassiz SEF of 2.9 and CEF of 2.7. The Dye $3 c$-axis concentration profile (Herron and others, 1985) is similar to that of the Agassiz 77 core with Wisconsin half-cone angles of about $25^{\circ}$ and early Holocene of about $35^{\circ}$.

The Dye 3 bore hole was filled with a denser liquid than Agassiz 77 (Gundestrup and Hansen, 1984), resulting in a net over-pressure and hole-widening with time. Qualitatively, one can see that the Dye 3 bore hole opened more rapidly for the Wisconsin and/or "dirty" ice 


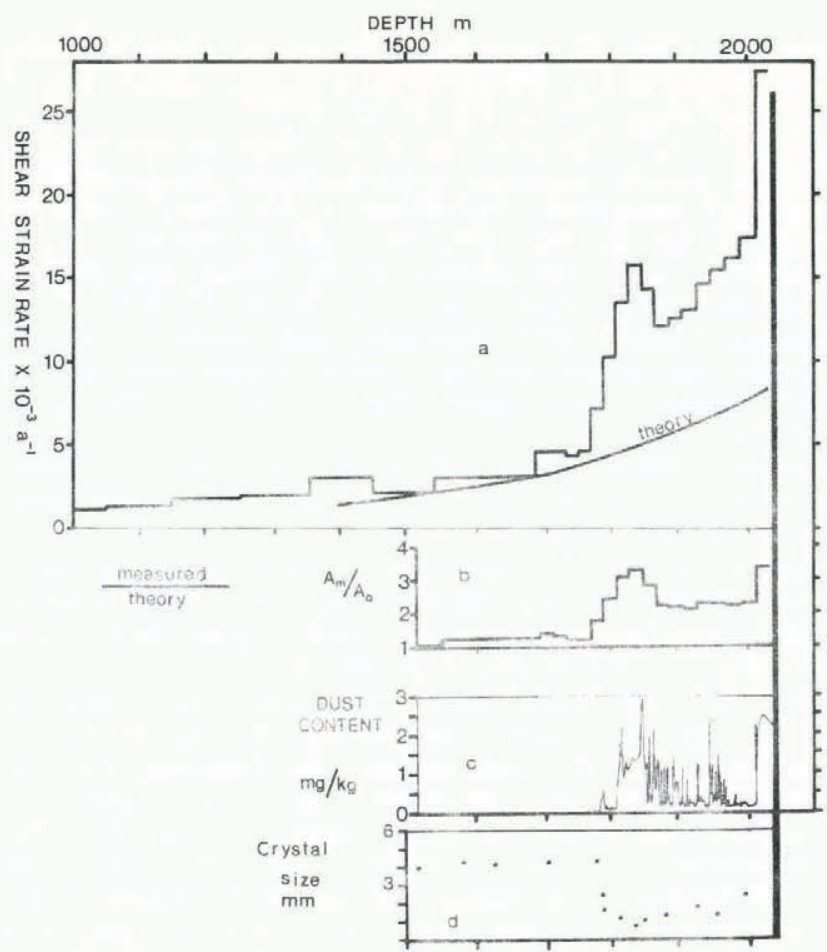

Fig. 10. a. Measured and theoretical tilt or shear strain-rates for the Dye 3 bore hole, south Greenland.

b. Shear-strain enhancement, SEF, factor for Dye 3.

c. Microparticle or dust concentration in Dye 3.

d. Crystal size in Dye 3 core.

(Gundestrap and Hansen, 1984). But, because of a complicated liquid-density profile, long drilling time, and missed field seasons in the diameter logging, no quantitative measure of "closure" enhancement can be made.

\section{THE ANISOTROPY PROBLEM}

Like Dahl-Jensen (1985) and Russell-Head and Budd (1979), we found that despite the increase in vertical $c$-axis concentration with depth, a single set of constants $A_{0}$ and $Q$ (see Equations (5) and (6)) in a non-linear $(n=3)$ flow law provided an adequate description of bore-hole tilt for post-Wisconsin ice. This would seem to contradict Lile's (1978) laboratory strain tests on $200 \mathrm{~m}$ deep samples from Law Dome core SGF. This ice has small $\alpha$ values and nearvertical $c$-axes. For simple shear stress $<0.04 \mathrm{MN} \mathrm{m}^{-2}$ (octahedral) and high temperatures $\left(-6^{\circ} \mathrm{C}\right)$, the $c$-axis enhancement is 2.8 (Lile's sample $200 \mathrm{~F} 1$ ). Lile's $c$-axis enhancement ratio is with respect to an equivalent piece of laboratory-produced isotropic ice. From laboratory tests on SGF cores, Russell-Head and Budd calculated $c$-axis enhancement factors of up to four in post-Wisconsin Law Dome ice.

For ice caps, the flow-law constants $Q$ and $A_{O}$ are usually chosen to produce a best fit to measured bore-hole tilt or tunnel-closure data. Since both temperature and $c$-axis concentration tend to increase together with depth, possibly both the $c$-axis and temperature enhancement are lumped together in the choice of the constants. This would explain why there seems to be no $c$-axis enhancement when one calculates the expected strain-rates using the best-fit $A_{0}$ and $Q$ constants.

Possibly, a clear example of $c$-axis enhancement can be seen in the deep ice of the Agassiz 77 core where there is a high near-vertical $c$-axis concentration. This ice (early Holocene and older) is well oriented for the shear responsible for bore-hole tilting and badly oriented for bore-hole closure. The $A_{0}$ constants for tilt and closure of this deep ice have a ratio of 10 , i.e. $A_{0}($ tilt $) / A_{0}$ (closure), in agreement with Paterson (1981) and Lile (1978). The laboratory tests of Lile (1978) on SFG Law Dome samples $200 \mathrm{~F} 1$ and 200F3, which were shear tests in the mostfavoured plane and at $45^{\circ}$ to it, gave a ratio of
$A_{\mathrm{O}}(200 \mathrm{~F} 1) / A_{0}(200 \mathrm{~F} 3)=12$.

The $A_{0}$ (tilt) $/ A_{\mathrm{o}}$ (closure) $=10$ ratio is constant for early Holocene ice and deeper (right through the Wisconsin and basal ice) in spite of the fact that the non-c-axis enhancements SEF and CEF vary between 1 and 3 (see Fig. 8).

\section{CONCLUSION}

Closure and shear enhancement for microparticle-laden and/or ice-age ice from Agassiz 77, Devon Island, and Dye 3 does exist and, where known, is about three. From the Agassiz 77 closure data, it appears that transient $\dot{\epsilon}_{1}$ and tertiary $\dot{\epsilon}_{3}$ creep-rates are also enhanced by the presence of high particle concentrations. Of the quantities measured on the Agassiz 77 cores, microparticle concentration (or $\mathrm{Ca}$ ) correlated best with enhancement factors. Also, for the microparticle concentrations greater than $15000(>1 \mu \mathrm{m} / \mathrm{ml})$, there is a clear inverse relationship with crystal size for Agassiz and Devon Island. In addition, there is a visible inverse relationship for the Dye 3 cores between crystal size and microparticle mass. The lack of a clear relationship between microparticles, crystal size, and flow enhancement in Antarctic ice is probably because this ice is an order of magnitude "cleaner" in microparticles and rarely gets above the threshold value.

There can be little doubt that there is a rheological enhancement factor of up to three that is related to impurities in natural ice, particularly in Northern Hemisphere late Wisconsin ice. In future, modellers should keep this in mind when reconstructing ancient ice sheets, that would consist largely of microparticle- (calcium-rich) laden ice.

\section{ACKNOWLEDGEMENTS}

W.S.B. Paterson's critical review of this paper and his earlier work on this topic have been invaluable. Discussions and data exchange with N. Reeh, D. Dahl-Jensen, and N. Gundestrup have been very helpful to us.

\section{REFERENCES}

Azuma, N. Unpublished. Mechanical properties and textural change of Antarctic deep ice cores. [M.Sc. thesis, Hokkaido University, 1982.]

Boutron, C. 1979. Trace element content of Greenland snows along an east-west transect. Geochimica et Cosmochimica Acta, Vol. 43, No. 8, p. 1253-58.

Budd, W.F. 1969. The dynamics of ice masses. Australian National Antarctic Research Expedition Reports, Ser. Vol. 4, Glaciology. (Publication No. 108.)

Cragin, J.H., and others. 1977. Interhemispheric comparison of changes in the composition of atmospheric precipitation during the late Cenozoic era, by J.H. Cragin, M.M. Herron, C.C. Langway, jr, and G. Klouda. (In Dunbar, M.J., ed. Proceedings of the Polar Oceans Conference held at McGill University, Montreal, May, 1974. Calgary, Alberta, Arctic Institute of North America, p. 617-31.)

Dahl-Jensen, D. 1985. Determination of the flow properties at Dye 3, south Greenland by bore-hole-tilting measurements and perturbation modelling. Journal of Glaciology, Vol. 31, No. 108, p. 92-98.

Fisher, D.A. 1981. General discussion during the Symposium on Processes of Glacier Erosion and Sedimentation, Geilo, Norway. Annals of Glaciology, Vol. 2, p. 192.

Fisher, D.A., and Koerner, R.M. 1981. Some aspects of climatic change in the High Arctic during the Holocene as deduced from ice cores. (In Mahaney, W.C., ed. Quaternary paleoclimate. Norwich, GeoAbstracts, p. 249-71.)

Fisher, D.A., and others. 1983. Effect of wind scouring on climatic records from ice-core oxygen-isotope profiles, by D.A. Fisher, R.M. Koerner, W.S.B. Paterson, W. Dansgaard, N. Gundestrup, and N. Reeh. Nature, Vol. 301, No. 5897, p. 205-09.

Gifkins, R.C. 1970. Optical microscopy of metals. New York, American Elsevier Publishing Co. 
Gundestrup, N.S., and Hansen, B.L. 1984. Bore-hole survey at Dye 3, south Greenland. Journal of Glaciology, Vol. 30 , No. 106 , p. 282-88.

Hammer, C.U. 1977. Past volcanism revealed by Greenland ice sheet impurities. Nature, Vol. 270, No. 5637, p. $482-$ 86.

Hammer, C.U., and others. 1985. Continuous impurity analysis along the Dye 3 deep core, by C.U. Hammer, H.B. Clausen, W. Dansgaard, A. Neftel, P. Kristinsdottir, and E. Johnson. (In Langway, C.C., jr, and others, eds. Greenland ice core: geophysics, geochemistry, and the environment, edited by C.C. Langway, jr, H. Oeschger, and $W$. Dansgaard. Washington, DC, p. 90-94. (Geophysical Monograph 33.))

Hansen, B.L., and Landauer, J.K. 1958. Some results of ice cap drill hole measurements. Union Géodésique et Géophysique Internationale. Association Internationale d'Hydrologie Scientifique. Symposium de Chamonix 16-24 sept. 1958, p. 313-17. (Publication No. 47 de l'Assocation Internationale d'Hydrologie Scientifique.)

Herron, S.L., and Langway, C.C., jr. 1982. A comparison of ice fabrics and textures at Camp Century, Greenland and Byrd Station, Antarctica. Annals of Glaciology, Vol. 3, p. 118-24.

Herron, S.L., and others. 1985. Ultrasonic velocities and crystalline anisotropy in the ice core from Dye 3, Greenland, by S.L. Herron, C.C. Langway, jr, and K.A.Brugger. (In Langway, C.C., jr, and others, eds. Greenland ice core: geophysics, geochemistry, and the environment, edited by C.C. Langway, jr, H. Oeschger, and $W$. Dansgaard. Washington, DC, American Geophysical Union, p. 23-31. (Geophysical Monograph 33.))

Hooke, R.L. 1973. Structure and flow in the margin of the Barnes ice cap, Baffin Island, N.W.T., Canada. Journal of Glaciology, Vol. 12, No. 66, p. 423-38.

Koerner, R.M. 1977. Discussion of L.G. Thompson's paper. [Union Géodésique et Géophysique Internationale. Association Internationale des Sciences Hydrologiques. Commission des Neiges et Glaces.] Symposium. Isotopes et impuretés dans les neiges et glaces. Actes du colloque de Grenoble, août/septembre 1975, p. 363. (IAHS-AISH Publication No. 118.)

Koerner, R.M., and Fisher, D.A. 1979. Discontinuous flow, ice texture, and dirt content in the basal layers of the Devon Island ice cap. Journal of Glaciology, Vol. 23, No. 89 , p. $209-22$.

Lile, R.C. 1978. The effect of anisotropy on the creep of polycrystalline ice. Journal of Glaciology, Vol. 21, No. 85, p. 475-83.
Nye, J.F. 1952. A comparison between the theoretical and the measured long profile of the Unteraar Glacier. Journal of Glaciology, Vol. 2, No. 11, p. 103-07.

Nye, J.F. 1953. The flow law of ice from measurements in glacier tunnels, laboratory experiments and the Jungfraufirn borehole experiment. Proceedings of the Royal Society of London, Ser. A, Vol. 219, No. 1139, p. 477-89.

Nye, J.F. 1959. The motion of ice sheets and glaciers. Journal of Glaciology, Vol. 3, No. 26, p. 493-507.

Paterson, W.S.B. 1977. Secondary and tertiary creep of glacier ice as measured by borehold closure rates. Reviews of Geophysics and Space Physics, Vol. 15, No. 1, p. 47-55.

Paterson, W.S.B. 1981. The physics of glaciers. Second edition. Oxford, etc., Pergamon Press (Pergamon International Library.)

Paterson, W.S.B. 1983. Deformation within polar ice sheets: an analysis of the Byrd Station and Camp Century borehole-tilting measurements. Cold Regions Science and Technology, Vol. 8, No. 2, p. 165-79.

Reeh, N., and others. 1985. Dating the Dye 3 deep ice core by flow model calculations, by N. Reeh, S.J. Johnsen, and D. Dahl-Jensen. (In Langway, C.C., jr, and others, eds. Greenland ice core: geophysics, geochemistry and the environment. Edited by C.C. Langway, jr, $H$. Oeschger, and $W$. Dansgaard. Washington, DC, p. 57-65. (Geophysical Monograph 33.))

Russell-Head, D.S., and Budd, W.F. 1979. Ice-sheet flow properties derived from bore-hole shear measurements combined with ice-core studies. Journal of Glaciology, Vol. 24, No. 90 , p. 117-30.

Shoji, H., and Langway, C.C., jr. 1984. Flow behavior of basal ice as related to modeling considerations. Annals of Glaciology, Vol. 4, p. 141-48.

Thompson, L.G. 1977. Variations in microparticle concentration, size distribution and elemental composition found in Camp Century, Greenland and Byrd Station, Antarctica, deep ice cores. [Union Géodèsique et Géophysique Internationale. Association Internationale des Sciences Hydrologiques. Commission des Neiges et Glaces.] Symposium. Isotopes et impuretés dans les neiges et glaces. Actes du colloque de Grenoble, août/septembre 1975, p. 351-64. (IAHS-AISH Publication No. 118.)

Thwaites, R.J., and others. 1984. Relationship between bore-hole closure and crystal fabrics in Antarctic ice core from Cape Folger, by R.J. Thwaites, C.J.L. Wilson, and A.P. McCray. Journal of Glaciology, Vol. 30, No. 105, p. 171-79. 